\title{
Potensi Dan Paradigma Nazir Terhadap Aset Wakaf Tanah Di Kabupaten Tapanuli Selatan
}

\author{
Damri Batubara \\ Institut Agama Islam Negeri Padangsidimpuan \\ JL. H.T. Rizal Nurdin Km 4,5 Sihitang Kota Padangsidimpuan - Sumatera Utara \\ Email: damri.batubara1234@gmail.com
}

\begin{abstract}
Abstrak
Wakaf tanah merupakan salah satu pilar dalam menyelesaikan permasalahan kesenjangan perekonomian ummat. Ini bisa terealisasi bila wakaf tanah tersebut dikelola dengan baik dan produktif. Agar aset wakaf lebih produktif dan semakin efektif, tergantung bagaiamana cara pengelolaan para nazirnya. Oleh sebab itu, para nazir harus membangun paradigma baru dalam pengelolaan aset wakaf. Dari data wakaf tanah yang ada di Kabupaten Tapanuli Selatan, potensi wakaf tanahnya mencapai $411 \mathrm{H}_{\mathrm{a}}$. Akan tetapi potensi ini tidak berarti apa-apa bagi perkembangan ekonomi ummat. bahkan konsumtif semata untuk tempat ibadah saja. Sementara dalam UUD, Peraturan Pemerintah dan KHI mendukung penuh wakaf tanah harus dikembangkan dalam menunjang perekonomian dan dikelola secara produktif sesuai syariah oleh para nazir yang bersangkutan. Penelitian ini adalah penelitian kualitatif dengan bentuk deskriptif. Teknik Pengambilan datanya observasi, wawancara dan dokumentasi. Teknik pengolahan datanya adalah editing data dan reduksi data dan penarikan kesimpualan.
\end{abstract}

\section{Keywods: Potensi, Paradigma, Wakaf Tanah}

\begin{abstract}
Land waqf is one of the pillars in solving the problem of economic disparities in the ummah. This can be realized if the land waqf is managed properly and productively. In order for waqf assets to be more productive and more effective, it depends on how the nazirs are managed. Therefore, the nazir must build a new paradigm in the management of waqf assets. From the land waqf data in South Tapanuli Regency, the potential for land waqf reaches 411 hectares. However, this potential means nothing for the economic development of the ummah. even consumptive only for places of worship. Meanwhile in the Constitution, Government Regulation and KHI fully support land waqf must be developed in support of the economy and managed productively according to sharia by the nazir concerned. This research is a qualitative research with descriptive form. Data collection techniques are observation, interview and documentation. Data processing techniques are data editing and data reduction and drawing conclusions.
\end{abstract}

Keywods: Potential, Paradigm, Land Waqf 


\section{PENDAHULUAN}

Di tengah problem sosial masyarakat dan tuntutan kesejahteraan ekonomi. Eksistensi lembaga wakaf menjadi sangat strategis. Wakaf merupakan pilar peyangga bagi tegaknya institusi-institusi sosial keagamaan masyarakat muslim berabad-abad. Hal itu dilakukan melalui penyediaan dana dan sarana pendukung bagi kegiatan-kegiatan ritual keagamaan, pendidikan, pengembangan ilmu pengetahuan, seni dan budaya. Bahkan apabila dikelola secara produktif, wakaf akan mampu menjalankan fungsi yang lebih lagi, misalnya penyediaan sarana umum, seperti jalan, jembatan, air minum, taman-taman kota, tempat pemandian umum dan sebagainya. Tujuan tujuan dari wakaf ini sejalan dengan paradigma kemaslahatan yang menjadi orientasi dari syariat Islam.

Agar aset wakaf lebih produktif dan semakin efektif, para nazir harus membangun paradigma baru dalam pengelolaan aset wakaf. Dalam membanguan paradigma baru wakaf ini, langkah yang pertama ditempuh adalah meletakkan asas paradigma baru ini. Ada beberapa hal yang berkaitan dengan asas paradigma wakaf produktif (Abdurrahman Kasdi dan Moerdiyanto 2017).

Pertama, asas keabadian manfaat. Subtansi perintah Rasulullah kepada umar bin Khattab untuk menyedekahkan tanah di khaibar adalah agar kebun tersebut tidak diperjual belikan, dihibahkan atau diwariskan dan hasilnya disedekahkan untuk kepentingan umat.

Kedua, asas pertanggung jawaban. Sebagai sebuah ajaran yang memiliki dimensi ilahiyah dan insaniyah, wakaf harus bisa dipertanggung jawabkan baik dunia maupun akhirat.

Ketiga, asas profesionalitas manajemen. Prinsif profesionalitas dalam pengelolaan harta wakaf menempati posisi yang paling urgen. Karena yang menentukan asset wakaf bermanfaat atau tidak tergantung pada pola pengelolaannya, bagus atau buruk.

Keempat, asas keadilan sosial. Sebagai salah satu aspek ajaran Islam yang berdimensi sosial, wakaf menempati posisi penting dalam upaya membangun suatu sistem sosial yang berkeadilan dan berkesejahteraan.

Begitu juga dalam peraturan Departemen Agama pada 22 Desember 1953 tentang prosedur pemberian tanah wakaf, yang kemudian diataur kembali oleh surat edaran Departemen Agama No 5/D/1956. Kemudian diterbitkannya undang-undang Nomor 5 Tahun1960 tentang peraturan dasar pokok-pokok agraria. Dalam Undang-undang ini, aset wakaf mendapatkan dasar hukum yang tetap, dimana Negara secara resmi menyatakan perlindungan terhadap harta wakaf. Selanjutnya, dipertegas kembali dalam peraturan pemerintah No 10 Tahun 1961 tentang pendaftaran tanah. Peraturan ini meningkatkan penertiban sertifikasi tanah atas tanah wakaf yang telah diikrarkan. 
Setelah mendapatkan perlindungan dari pemerintah, eksistensi wakaf semakin mendapatkan tempat dengan terbitnya peraturan pemerintah No 28 Tahun 1977 tentang perwakafan tanah milik, yang memuat unsur-unsur substansi dan teknis perwakafan. Yaitu, memberikan legalitas membolehkan pertukaran harta wakaf setelah mendapat izin dari Menteri Agama, supaya dapat diberdayakan secara optimal.

Selanjutnya intruksi Presiden No 1 Tahun 1991 tentang Kompilasi Hukum Islam (KHI) dengan tujuan elaborasi dan unifikasi mazhab dan Hukum Islam di Indonesia. Beberapa perluasan aturan perwakafan dalam KHI antara lain, berkaitan dengan objek wakaf, nazir dan sebagainya. Terkait dengan objek wakaf telah mencakup harta benda bergerak. Demikian halnya dengan nazir dalam KHI jumlah nazir perseorangan tidak lagi dibatasi hanya sebanyak tiga orang, melainkan disesuaikan dengan kebutuhan manajemen wakaf.

Kemudian lahir undang-undang No 41 Tahun 2004 tentang wakaf dengan tujuan pokok untuk mendorong kemajuan pengelolaan wakaf di Indonesia. Dengan Undang-undang ini, sector wakaf diharapkan mampu berfungsi sedemikian rupa, sehingga mendukung kesejahteraan sosial ekonomi ummat Islam. Kemudian Peraturan pemerintah RI No 42 Tahun 2006 tentang pelaksanaan Undang-undang No 41 Tahun 2004 tentang wakaf, keputusan Menteri Agama No 4 Tahun 2009 tentang administrasi pendaftaran wakaf uang, dan peraturab Menteri Agama RI No 73 Tahun 2013 tentang tatacara perwakafan benda tidak bergerak dan benda bergerak selain uang.

Dari ke empat asas paradigma baru dalam pengembangan aset wakaf di atas dan juga regulasi yang mendukung menentukan baik dan buruknya aset wakaf berada di tangan para nazir wakaf. Apakah nazir mengikuti paradigma baru atau tetap mengikuti paradigma lama.

Bila di lihat dari aset wakaf tanah di Kabupaten Tapanuli Selatan sangat berpotensi dan luas, hingga mencapai $411\left(\mathrm{H}_{\mathrm{a}}\right), 197\left(\mathrm{H}_{\mathrm{a}}\right)$ Sudah Sertifikat dan $214\left(\mathrm{H}_{\mathrm{a}}\right)$ yang belum sertifikat. Pengguna aset wakaf tersebut diperuntukkan kepada 6 bentuk. Sebagaimana tertera dalam tabel di bawah ini.

Tabel 1

Aset Tanah Wakaf

Kabupaten Tapanuli Selatan Sumatera Utara

\begin{tabular}{|l|l|c|c|c|}
\hline No & Nama Aset Tanah Wakaf & $\begin{array}{c}\text { Sudah } \\
\text { Sertifikat }\end{array}$ & $\begin{array}{c}\text { Belum } \\
\text { Sertifikat }\end{array}$ & Total Jumlah \\
\hline $\mathbf{1}$ & Tanah Wakaf Masjid & $38(\mathrm{Ha})$ & $47(\mathrm{Ha})$ & $85(\mathrm{Ha})$ \\
\hline $\mathbf{2}$ & Tanah Wakaf Musallah & $100(\mathrm{Ha})$ & $103(\mathrm{Ha})$ & $\mathbf{2 0 3}(\mathrm{Ha})$ \\
\hline 3 & Tanah Wakaf Maqam & $31(\mathrm{Ha})$ & $32(\mathrm{Ha})$ & $63(\mathrm{Ha})$ \\
\hline 4 & Tanah Wakaf Pesantren & $1(\mathrm{Ha})$ & $6(\mathrm{Ha})$ & $7(\mathrm{Ha})$ \\
\hline 5 & Tanah Wakaf Sekolah & $\mathbf{2 5}(\mathrm{Ha})$ & $\mathbf{2 3}(\mathrm{Ha})$ & $48(\mathrm{Ha})$ \\
\hline 6 & Tanah Wakaf Sosial & $2(\mathrm{Ha})$ & $3(\mathrm{Ha})$ & $5(\mathrm{Ha})$ \\
\hline
\end{tabular}

JISFIM: Journal of Islamic Social Finance Management, Volume 1, No 2 Tahun 2020 http://jurnal.iain-padangsidimpuan.ac.id/index.php/JISFIM 


\begin{tabular}{|c|c|c|c|c|}
\hline Jlh & $197(\mathrm{Ha})$ & $214(\mathrm{Ha})$ & $411_{(\mathrm{Ha})}$ \\
\hline
\end{tabular}

Sumber data diolah: Direktorat Pemberdayaan Wakaf, Direktorat Jenderal Bimbingan Masyarakat Islam Kementerian Agama Republik Indonesia.

Tetapi, besarnya aset wakaf tanah ini, tidak menjadikan berarti apa-apa dalam kesejehteraan ekonomi. Hampir 90 \% konsumtif dalam bidang ibadah amaliah semata, tidak menyentuh ke bidang sosial perekonomian. Seharusnya asas paradigma para nazir aset wakaf tanah beruapa mengembangkan dengan skill dan inovasi baru sampai menyentuh perbaikan ekonomi dan kesejahteraan masayarakat.

Sebab itu, perlu dilakukan penelitian mendalam mengenai Ppotensi dan paradigma nazir dalam pengembangan aset wakaf yang ada di Kabupaten Tapanuli Selatan.

\section{METODE PENELITIAN}

Penelitian ini adalah penelitian kualitatif dengan metode deskriptif. Penelitian kualitatif adalah riset yang bersifat deskriptif dan cenderung menggunakan analisis dengan pendekatan induktif dan dilakukan pada kondisi alamiah dan bersipat penemuan (Noor 2011).

Atau dapat disebut juga sebagai penelitian yang dalam pengumpulan data dan penafsirannya tidak menggunakan rumus-rumus statistik. Motode deskriptif adalah suatu metode dalam meneliti status kelompok manusia, suatu objek, suatu set kondisi, suatu sistem pemikiran, dengan tujuan untuk membuat deskripsi, gambaran atau lukisan sistematis, faktual dan akurat, mengenai fakta-fakta serta hubungan fenomena yang diselidiki. (Nizar 2011).

Subjek dalam penelitian adalah para nazir asset wakaf tanah, lembaga kenaziran wakaf tanah, baik ia wakaf tanah Masjid. wakaf tanah Musallah, wakaf tanah Maqam, wakaf tanah Pesantren, wakaf tanah Sekolah, dan wakaf tanah Sosial lainnya.

\section{Sumber Data}

Penelitian ini dilakukan dengan cara mempelajari dan menganalisa data-data penelitian, yang dikelompokkan menjadi 3 bagian.

Data primer, yaitu berupa hasil wawancara dengan pengelola asset wakaf tanah (nadhir) di Kabupaten Tapanuli Selatan baik yang bersifat perorangan maupun lembaga.

Sekunder, yaitu data yang diambil dari hasil studi pustaka yang bertujuan untuk memperoleh landasan teori yang bersumber dari buku literatur dan karya ilmiah lainnya yang berkaitan dengan asset wakaf tanah.

Tersier, adalah berupa kamus, Brosur dan data lainnya yang dapat di jadikan sumber data pendukung.

JISFIM: Journal of Islamic Social Finance Management, Volume 1, No 2 Tahun 2020 http://jurnal.iain-padangsidimpuan.ac.id/index.php/JISFIM 


\section{Teknik Pengumpulan Data}

Teknik pengumpulan data adalah alat bantu yang dipilih dan digunakan oleh peneliti dalam mengumpulkan data, agar kegiatan penelitian menjadi mudah dan sitematis. Adapun teknik pengumpulan data dalam penelitian ini adalah:

\section{Penelitian Lapangan \\ Observasi}

Observasi merupakan salah satu teknik operasional pengumpulan data melalui proses pencatatan secara cermat dan sistematis terhadap objek yang diamati secara langsung. Observasi yang dilakukan pada penelitian ini adalah observasi langsung ke tanah perwakafan yang ada di Kabupaten Tapanuli Selatan.

\section{Wawancara}

Wawancara yang dilakukan peneliti (interviewer) terhadap responden bersifat terbuka, dimana dua orang atau lebih berhadapan secara fisik yang satu dapat melihat yang lain, serta mendengarkan suaranya dengan telinga sendiri. Pedoman yang wawancara yang digunakan dalam penelitian ini berdasarkan pelaksanaannya mengacu pada interview, peawancara menanyakan pada informan dengan pertanyaan yang telah terstruktur kemudian satu persatu diperdalam mengorek keterangan lebih lanjut. Keduanya dipadukan penulis, untuk menciptakan suasana interview yang lebih santai tetapi terarah. Sehingga, informan bebas menjawab pertayaan tersebut sesuai pokok pikirannya. Setelah peneliti merasa sudah cukup atas kebutuhan penelitian, baru peneliti akhiri pertayaan kepada responden (Arikunto 2010).

\section{Dokumentasi}

Selain dari observasi dan wawancara bentuk alat pengumpulan data adalah dokumentasi. Dokumentasi yang dilakukan disini pencarian data-data mengenai hal-hal berupa catatan, buku-buku, majalah, dokumen dan sebagainya (Arikunto 2010) yang ada kaitannya dengan aset wakaf tanah yang ada di lapangan.

\section{Tinjauan Kepustakaan}

Tinjauan pustaka ini adalah bertujuan untuk menghimpun dan menganalisis data yang bersumber dari perpustakaan yang dijadikan sebagai sumber rujukan untuk penyusunan suatu analisis penelitian.

JISFIM: Journal of Islamic Social Finance Management, Volume 1, No 2 Tahun 2020 http://jurnal.iain-padangsidimpuan.ac.id/index.php/JISFIM 


\section{Teknik Pengolahan dan Analisis Data}

Teknik yang dilakukan dalam pengolahan data penelitian ini yaitu, Deskriptif Kualitatif. Yaitu, penelitian yang berusaha menggambarkan secara sistematik fakta dan karakteristik objek atau subjek yang diteliti secara tepat (Sukardi 2003). Atau menginterprentasikan objek sesuai dengan apa adanya dengan bentuk tulisan, atau disebut dengan penelitian non eksperimen.

Kemudian melakukan analisis data dengan proses mencari dan menyusun urutan data secara sistematis yang diperoleh dari hasil wawancara, catatan lapangan, dokumentasi, dengan cara mengorganisasi data kedalam kategori, menjabarkan kedalam unit-unit, melakukan sintesa, menyusun kedalam pola memilih mana yang penting dan yang akan dipelajari dan membuat kesimpulan, sehingga mudah dipahami oleh diri sendiri maupun orang lain. Setelah data terkumpul, maka dilaksanakan pengelolahan dan analisis data dengan teknik berikut:

Editing data, yaitu reduksi data menjadi suatu susunan kalimat yang sistematis

Reduksi data, yaitu memeriksa kelengkapan data untuk mencari data yang masih kurang dan mengesampingkan yang tidak relevan (Sugiyoni 2017).

Deskripsi data, yaitu menguraikan data secara sistematis untuk mendeskripsikan pelaksanaan penelitian induksi dan deduktif sesuai dengan sistematika pembahasan.

Penarikan kesimpulan, yaitu kegiatan analisis dengan menarik kesimpulan dan verifikasi. Mula-mula kesimpulan kabur, tapi lama kelamaan semakin jelas karena data semakin banyak dan mendukung.

\section{Teknik Pengecekan Keabsahan Data}

Keabsahan data merupakan konsep penting yang harus diperbaharui dari konsep keahlian (validitas) dan keandalan (reliabilitas) dan sesuai dengan tuntutan pengetahuan. Adapun pengecekan data yang digunakan adalah.

Perpanjangan keikutsertaan

Keikut sertaan penelitian sangat menentukan dalam pengumpulan data, keikut sertaan tersebut tidak hanya dilakukan dengan waktu singkat, tetapi memerlukan perpanjangan JISFIM: Journal of Islamic Social Finance Management, Volume 1, No 2 Tahun 2020 http://jurnal.iain-padangsidimpuan.ac.id/index.php/JISFIM 
keikutsertaan peneliti pada latar penelitian. Tujuannya untuk membangun drajat kepercayaan data yang dikumpulkan.

Ketentuan pengamatan

Ketentuan pengamatan bermaksud menemukan cirri-ciri dan unsure-unsur dalam situasi yang sangat relevan dengan persoalan atau isu yang sedang dicari dan kemudian memutuskan dari hal-hal tersebut secara rinci. Teknik ini menuntut agar peneliti mampu menguraikan secara tentatif dan penelaahan secara rinci dapat dilakukan.

Menggunakan bahan Referensi

Tujuan bahan referensi ini untuk mendukung data yang telah ditemukan oleh peneliti. Sebagai contoh, data hasil wawancara perlu didukung dengan adanya rekaman wawancara atau didukung foto-foto.

Mengadakan memberchek

Memberchek adalah proses pengecekan data yang diperoleh peneliti kepada pemberi data. Tujuan memberchek adalah untuk mengetahui seberapa jauh data yang diperoleh sesuai dengan apa yang diberikan oleh pemberi data.

Triangulasi

Triangulasi adalah teknik pengumpulan data yang bersifat menggabungkan dari berbagai teknik pengumpulan data dan sumber data yang telah ada.

\section{HASIL DAN PEMBAHASAN}

\section{Potensi Wakaf Tanah Kabupaten Tapanuli Selatan Potensi Wakaf Tanah}

Jumlah tanah wakaf di Sumatera Utara cukup banyak dan luas, dari data sistem wakaf Kemenag (siswak), wakaf tanah Sumatera Utara mencapai 15.457 lokasi, dengan luas 15.652,81

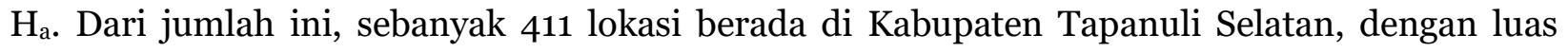
67,95 $\mathrm{H}_{\mathrm{a}}$ atau 0,09 \% berada di Tapanuli Selatan. Lebih jelas lihat gambar di bawah ini, menjelaskan tentang jumlah dan luas wakaf tanah di Kabupaten Tapanuli Selatan. 


\section{Gambar 1}

\section{Jumlah Wakaf Tanah Kab. Tapanuli Selatan}

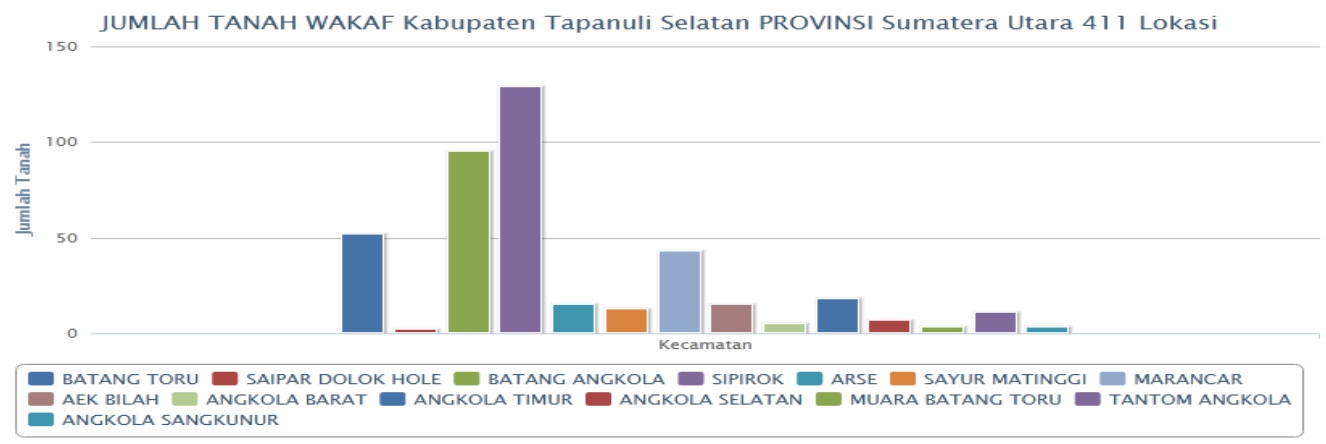

Gambar 2

Luas Wakaf Tanah Kab Tapanuli Selatan

LUAS TANAH WAKAF Kabupaten Tapanuli Selatan PROVINSI Sumatera Utara 67,95 Ha 200000

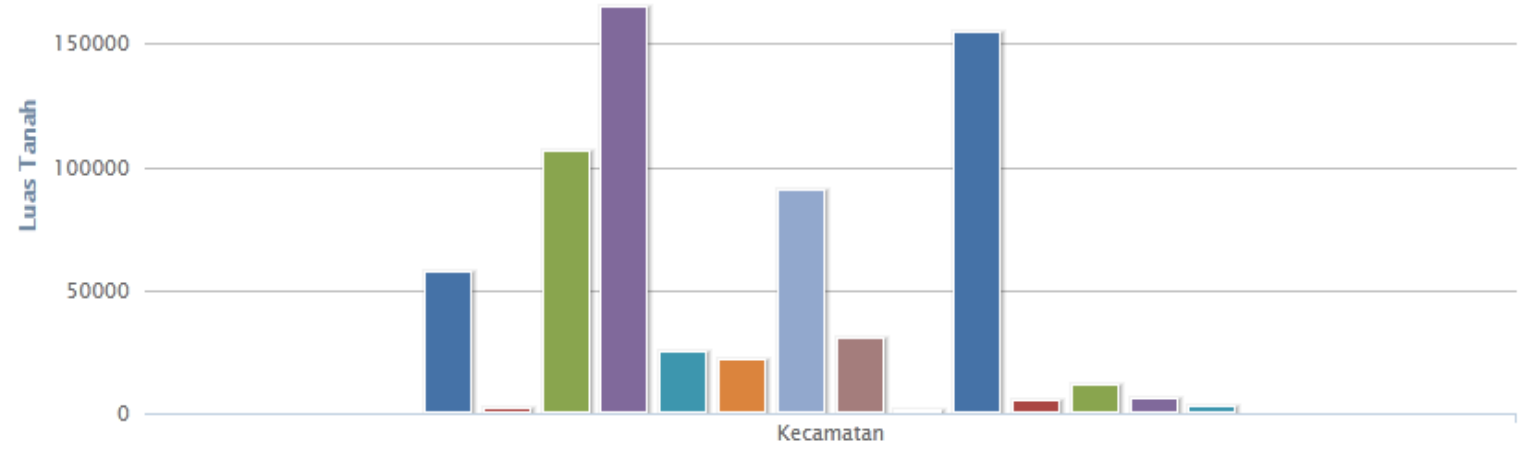

BATANG TORU $\square$ SAIPAR DOLOK HOLE $\square$ BATANG ANGKOLA $\square$ SIPIROK $\square$ ARSE $\square$ SAYUR MATINGGI MARANCAR AEK BILAH $\square$ ANGKOLA BARAT $\square$ ANGKOLA TIMUR $\square$ ANGKOLA SELATAN $\square$ MUARA BATANG TORU $\square$ TANTOM ANGKOLA ANGKOLA SANGKUNUR

Dari gamabar ini, tanah wakaf di Kabuapten Tapanuli Selatan ini cukup luas dan menggembirakan. Namun demikian, wakaf tanah ini banyak bermasalah, karena sebanyak 47,93 \% yang baru sertifikasi, sedangkan sisanya 52,07 \% belum sertifikasi sama sekali. Tingginya wakaf tanah yang belum sertifikasi seperti ini sangat rawan terhadap berbagai masalah perdata maupun pidana.

Wakaf tanah yang luas seharusnya memberikan potensi yang besar perkembangan ekonomi ketika diberdayakan semaksimal mungkin. Tetapi, pemanfaatan dan penggunaannya hanya bersipat passif (konsuntif) tidak diberdayakan sesuaian undangundang dan tuntunan yang telah diatur dalam syariat Islam yaitu wakaf tanah wajib bersipat aktif (produktifkan) dikelolah oleh nazir.

JISFIM: Journal of Islamic Social Finance Management, Volume 1, No 2 Tahun 2020 http://jurnal.iain-padangsidimpuan.ac.id/index.php/JISFIM 
Dari data skunder yang dikeluarkan oleh Kementerian Agama Kabupaten Tapanuli Selatan, Provinsi Sumatera Utara klasifikasi wakaf tanah terdiri dari lima jenis penggunaan dan pemanfaatan. Yaitu, Wakaf Tanah Masjid, Wakaf Tanah Mushallah, Wakaf Tanah Makam, Wakaf Tanah Pesantren, Wakaf Tanah Sekolah dan Wakaf Tanah Sosial Lainnya. Terlihat dari gambar di bawah ini:

\section{Gambar 3}

\section{Klasifikasi Wakaf Tanah Kab Tapanuli Selatan}

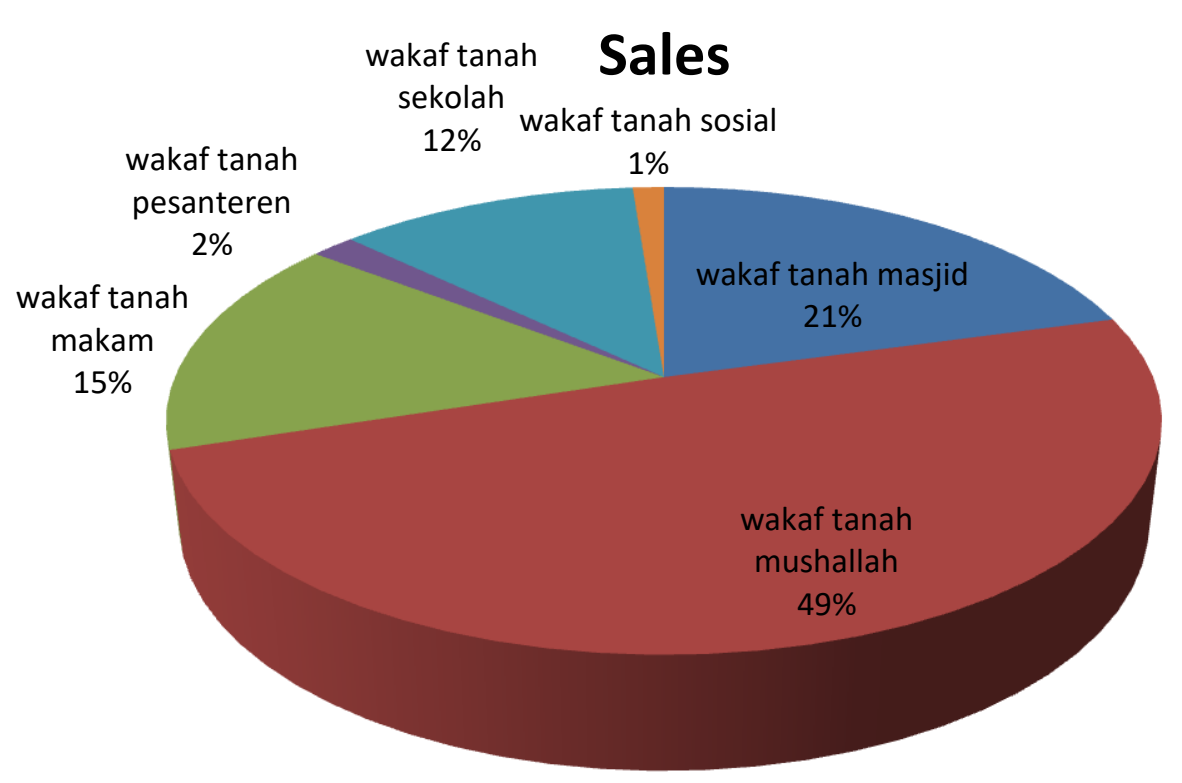

Berdasarkan gambar di atas, penggunaan dan pemanfaatan wakaf tanah yang paling besar adalah Mushallah sebanyak 49 \%, Wakaf Masjid 21 \%, Wakaf Tanah Makam 15 \%, Wakaf tanah sekolah 12 \%, wakaf Tanah Pesantern 2 \% dan Wakaf Tanah Sosial 1 \%. Yang paling besar tidak dimanfaatkan secara produktif dalam persfektif ekonomi Islam adalah wakaf tanah mushallah dan masjid. Kondisi pemanfaatan yang konsumtif seperti ini menyebabkan potensi wakaf tanah tidak produktif untuk penunjang perekonomian ummat.

Kondisi seperti ini, dikarenakan kurangnya inisiatif dan kreatif nazir dalam menyelesaikan permasalahan. Sekiranya pihak nazir mampu melakukan inisiatif dalam memberdayakan aset wakaf tanah dengan epektif dan produktif akan menunjuang perekonomian ummat, bahkan bisa jadi basis utama dalam menyelesaikan kemiskinan dan ketimpangan ekonomi. Meningkatkan kelestarian dan memberdayakan aset wakaf tanah secara produktif bisa dilakukan dengan cara-cara seperti: 
1) Menjalin hubungan kerja (Musyarakah) dengan pengusaha-pengusaha yang ada di sekitarnya, dengan akad-akad yang syar'i yang tidak melawan hukum maupun normanorma keagamaan

2) Menjalin sinergilitas dengan lembaga-lembaga keagaman, seperti, LAZ, BAZIS, BAZDA dan BASNAS, sehingga terjalin komunikasi yang aktif dalam memberdayakan wakaf tanah sekaligus mendapat insentifitas dari lembaga-lembaga tersebut

3) Mengajak masyarakat yang ada disekitarnya sama-sama membantu secara materi dan non materi untuk mengumpulkan modal untuk megelola dan memberdayakan wakaf tanah tersebut.

\section{Potensi Sumber Daya Insani (SDM)}

Potensi sumber daya insani merupakan salah satu indikator penilaian baik atau buruknya, berkembang atau tidaknya suatu wakaf tanah tersebut. Sumber daya Insani yang dimaksud adalah para nazir yang terlibat langsung dalam mengelola dan memberdayakan potensi wakaf tanah.

1) Bila dilihat dari potensi sumber daya manusianya (kuantitas) untuk mengelola dan mengembangkan wakaf tanah 99 \% cukup memiliki potensi dalam memberdayakan ekonomi. Sebab setiap wakaf tanah yang sudah sertifikat atau belum sertifikat, selalu ada nazir sebagai pengurus wakaf tersebut yang diangkat oleh masyarakat sekitar.

2) Potensi sumber daya manusianya dilihat dari segi keaktifan (kualitas) dalam mengelola dan memberdayakan wakaf tanah, hampir rata-rata tidak diberdayakan secara produktif, oleh para nazir, hanya dimanfaatkan secara konsuntif saja untuk tempat beribadah saja.

3) Sedangkan kalau dilihat dari potensi pendidikan para nazir, $10 \%$ Tamatan SD s, $15 \%$ Syanawiayah sederajat, 55 \% Aliyah sederajat dan 20 \% S1. Dari data ini, tentu kualitas pendidikan para nazir dalam mengembangkan wakaf tanah akan sangat mempengaruhi dalam mengembangkan produktifitas wakaf. Begitu juga skill dan inovasi yang tidak mendukung para nazir wakaf yang diawali dari rendahnya tingkat pendidikannya.

\section{Potensi Ekonomi}

Potensi ekonomi (modal) wakaf tanah merupakan salah satu hal yang sangat penting dalam memberdayakan dan mengembangkan ekonomi, karena ini akan menjadi modal ekonominya. Berdasarkan informan dari beberapa nazir yang ada di Kabupaten Tapanuli Selatan, potensi modal untuk memberdayakan dan mengembangakan wakaf tanah sangatlah 
minim. Jikapun ada hanya dari infak, shadaqoh dan para donator-donatur Masjid, Pesantren dan sekolah. Sementara wakaf tanah Makam, Mushallah dan Sosial lainnya tidak mempunyai modal sama sekali.

\section{PARADIGMA NAZIR ASET WAKAF TANAH}

Untuk mengetahui kondisi paradigma nazir dalam mengelola aset wakaf tanah di Kabupaten Tapanuli Selatan, sehingga memengaruhi terhadap berkembang tidaknya aset wakaf tersebut. sebagaimana di jelaskan di bawah ini.

Masih berkembangnya paradigm lama tentang pengelolaan wakaf, dimana aspek legalitas formal belum menjadi unsur penting dalam pengamanan harta benda wakaf. Sebagian masyarakat masih banyak orang yang mempercayai ketokohan agama sebagai Nazhir tanpa bukti-bukti tertulis. Mereka belum memiliki budaya tertib administrasi (pencatatan) pada instansi resmi KUA yang memiliki tugas pembinaan perwakafan di tingkat kecamatan.

Banyak harta benda wakaf, khususnya tanah, belum bersertifikat yang disebabkan oleh banyak hal, diantaranya adalah keengganan dan ketidaktahuan para Nazhir dalam mencatatkan harta benda wakaf kepada KUA dan pengurusan sertifikat di Badan Pertahanan Kabupaten/Kota yang terhitung rumit yang memakan waktu dan biaya yang cukup banyak serta ukuran yang tidak jelas. Meskipun di level pimpinan antara Kementerian Agama RI dengan Badan Pertanahan Nasional (BPN) telah terjadi kesepahaman tentang pentingnya sertifikasi tanah wakaf dan kemudahan prosesnya, namun di tingkat operasional (pelaksanaan) di lapangan ternyata mengalami banyak hambatan. Berbagai upaya untuk mengatasi hal tersebut telah dilakukan, seperti membentuk Tim Asistensi Sertifikasi dan Mutasi Harta Benda Wakaf yang dibentuk di berbagai wilayah di Indonesia dan Tim Pendataan Sertifikasi Harta Benda Wakaf.

Kapasitas Nazhir (pengelola wakaf) rata-rata tidak memiliki keterampilan (skill) dalam mengembangkan harta benda wakaf secara produktif. Jika ditilik dari keseluruhan performance Nazhir di seluruh Indonesia berdasarkan hasil riset PPIM UIN Syarif Hidayatullah Jakarta, bahwa lebih dari 80 persen Nazhir bekerja sambilan. Hal ini menunjukkan bahwa Nazhir sebagai poros utama dalam pemberdayaan wakaf belum memiliki power yang kuat dalam mengembangkan wakaf secara produktif. Terlebih lagi, di lingkungan Nazhir sendiri belum memiliki kesadaran massif akan pentingnya membangun kepercayaan kepada generasi muda untuk mengembangkan wakaf.

JISFIM: Journal of Islamic Social Finance Management, Volume 1, No 2 Tahun 2020 http://jurnal.iain-padangsidimpuan.ac.id/index.php/JISFIM 
Dalam banyak hal, muncul berbagai kasus sengketa tanah-tanah wakaf yang disebabkan oleh beberapa faktor, diantaranya adalah minimnya bukti-bukti administrative Negara sebagai pelindung hukum; perilaku sebagian Nazhir yang tidak bertanggung jawab, tindakan pihakpihak ketiga yang dengan sengaja mengambil paksa atau melanggar hokum untuk mengambil alih kepemilikan asset wakaf dengan cara-cara illegal. Disamping itu, banyak kasus tukar guling atau ruislah tanah wakaf yang dilakukan tidak sesuai dengan ketentuan yang berlaku yaitu karena alasan RUTR dan alasan keagamaan sebagai diatur dalam Undangundang Nomor 41 Tahun 2004 tentang Wakaf. Beberapa kasus mutasi harta benda wakaf yang sering ditemukan di lapangan adalah pelaksanaan ruislah dilakukan sebelum mendapat ijin dari Menteri Agama, atau mendapat tanah pengganti yang kurang layak dari tanah wakaf semula.

Belum terbangunnya sistem terpadu dalam pengelolaan dan pengembangan harta benda wakaf secara nasional, sehingga wakaf belum dapat berkembang secara lebih optimal. Memang telah diatur dalam Undang-undang, Peraturan Pemerintah, Peraturan Menteri Agama, dan Dirjen, namun masih mengalami kendala koordinatif di antara semua stakeholders yang ada. Dalam pengelolaan 7 wakaf produktif misalnya, masih ditemukan adanya ketidaksikronan antara Kementerian Agama dan berbagai lembaga wakaf lainnya. Belum adanya sinergi antar lembaga wakaf ini sangat mempengaruhi kinerja pengembangan wakaf untuk memajukan ekonomi umat.

\section{KESIMPULAN}

Dari hasil di atas, aset wakaf di Kabupaten Tapanuli Selatan sangat berpotensi baik dibidang Sumber daya Insannya maupun Aset wakafnya. Tetapi tidak berkembang dan produktif disebabkan kelemahan pengelolaannya (nazir) nya. Adapun kelemahannya antara lain kapasitas nazirnya lemah skill, tidak kreatif, tidak Inovatif dan tidak ada jiwa enterpereneursipnya, paradikma lama yang masih berakar, ketidaktahuan, keengganan, akibat kasus sengketa, sistem Yang Tidak Terpadu.

\section{DAFTAR PUSTAKA}

Abdurrahman Kasdi, dan Moerdiyanto. 2017. Pemberdayaan Wakaf Produktif Berbasis Wirausaha. Yogyakarta: Idea Press.

Arikunto, Suharsimi. 2010. Prosedur Penelitian Suatu Pendekatan Praktek. Cetakan 14. Jakarta: PT. Rineka Cipta.

Nizar, Muhammmad. 2011. Metode Penelitian. Bogor: Geralia Indonesia. 
Sugiyoni. 2017. Metode Penelitian Administrasi Dilengkapi Dengan Metode R \& D. Cetakan 24. Bandung: Alfabeta.

Sukardi. 2003. Metodologi Penelitian Pendidikan Kompetensi dan Prakteknya. Jakarta: Bumi Aksara.

Tuti A. Najib, Ridwan al-Makassary (ed), Wakaf, Tuhan, dan Agenda Kemanusiaan: Studi tentang Wakaf dalam Perspektif Keadilan Sosial di Indonesia, Jakarta: Kerjasama The Ford Foundation dan CSRC,

Abdurrahman Kasdi, Moerdianto, Pemberdayaan Wakaf Produktif Berbasis Wirausaha, Yogyakarta: Idea Press

Abdul Gafur Ansari, Hukum dan Praktik Perwakafan di Indonesia, Undang-undang Wakaf Nomor 41 Tahun 2004, Yogyakarta: Pilar Media

Kementerian Agama Republik Indonesia, Direktorat Jenderal Bimbingan Masyarakat Islam, Direktorat Pemberdayaan Zakat dan Wakaf, Himpunan Peraturan Perundangundangan Tentang Wakaf, Jakarta: Kementerian Agama Republik Indonesia, Direktorat Jenderal Bimbingan Masyarakat Islam, Direktorat Pemberdayaan Zakat dan Wakaf Munzir Qahaf, al-Waqf al-Islami, Syiria : Dar al-Fikr, 2006

JISFIM: Journal of Islamic Social Finance Management, Volume 1, No 2 Tahun 2020 http://jurnal.iain-padangsidimpuan.ac.id/index.php/JISFIM 